\title{
The Association of Intrauterine Antimicrobial Resistant Trueperella pyogenes with Cytological Endometrial Inflammation Status in Repeat Breeder Cows
}

\author{
Murat Onur Yazlık ${ }^{1}$, İnci Başak Müştak ${ }^{2 *}$, Gültekin Ünal ${ }^{3}$ and Ufuk Kaya ${ }^{4}$ \\ ${ }^{\prime}$ Department of Obstetrics and Gynecology, Faculty of Veterinary Medicine, Ankara \\ University, Ankara, Turkey \\ ${ }^{2}$ Department of Microbiology, Faculty of Veterinary Medicine, Ankara University, \\ Ankara, Turkey \\ ${ }^{3}$ Bioeksen Ar-Ge Technologies Co. Istanbul Technical University, ARI Technopark, \\ Istanbul, Turkey \\ ${ }^{4}$ Department of Biostatistics, Faculty of Veterinary Medicine, Hatay Mustafa Kemal \\ University
}

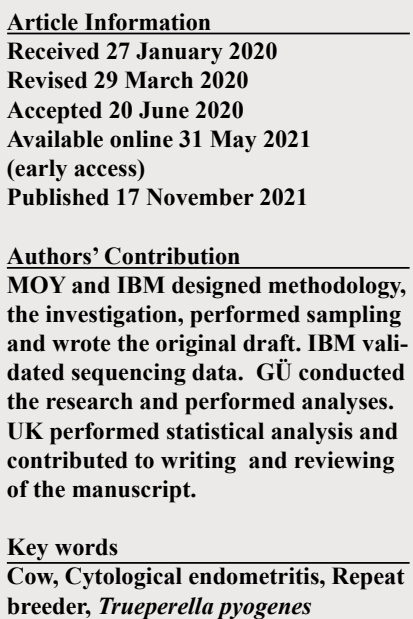

Key words

Cow, Cytological endometritis, Repeat

breeder, Trueperella pyogenes as T. pyogenes. These were combined to analyze the results by both biochemical and sequence analysis of the $16 \mathrm{~s}$ rDNA gene. Subclinical endometritis was detected in $37.5 \%$ cows. The T. pyogenes strains were highly resistant $(100 \%)$ to bacitracin, tetracycline, neomycin, and oxytetracycline. All tetracyclineresistant $T$. pyogenes strains were positive for the $t e t W$ gene. The variables had no effect on the presence of T. pyogenes in the repeat breeder cows. In conclusion, intrauterine T. pyogenes presence was not associated with subclinical endometritis, although $T$. pyogenes was detected in the later stages of lactation.

\section{INTRODUCTION}

$\mathrm{T}$ The key to economic success in dairy farming is good fertility. Postpartum uterine disorders reduce the reproduction success of high yielding cows (Huszenicza et al., 1999; Williams et al., 2007; Sheldon et al., 2009). Uterine disorders such as metritis, and clinical and subclinical endometritis have short and long-term effects on fertility (Gilbert et al., 2005; LeBlanc, 2008). Management style can also reduce fertility after parturition (Yazlik et al., 2018). After a successful postpartum period, repeat breeding is the most important fertility disorder in dairy cows (Yusuf et al., 2010). Repeat breeding is defined as a cow that has a normal estrus cycle free from palpable

\footnotetext{
* Corresponding author: ibkaya@ankara.edu.tr 0030-9923/2022/0001-0115 \$ 9.00/0

Copyright 2022 Zoological Society of Pakistan
}

clinical abnormalities and with no vaginal discharge that has failed to conceive after at least three or more inseminations (Heuwieser et al., 1997; Gustafsson and Emanuelson, 2002). Repeat breeding affects $10 \%-14 \%$ of dairy cows (Gustafsson and Emanuelson, 2002; Båge et al., 2002). Repeat breeding can be caused by estrus detection problems (Lopez-Gatius et al., 2004), prolonged estrus, delayed luteinizing hormone peak, rising progesterone after ovulation, genetic factors (Kendall et al., 2009) and infections (Pérez-Marin and España, 2007).

Endometrial cytology is a diagnostic technique used in repeat breeder cows. Cytotape is a novel diagnostic method for determining subclinical endometritis in cows (Pascottini et al., 2015), measured by the proportion of polymorph nuclear neutrophils (PMNs) in endometrial cells. The PMN threshold for defining subclinical endometritis varies according to the study from $\geq 3$ to $\geq$ $18 \%$ (Sheldon et al., 2006). The prevalence of subclinical 
endometritis in repeat breeder cows varies from $12.7 \%$ to $52.7 \%$ in dairy cows, i.e. subclinical endometritis is the main reason for becoming a repeat breeder (Salasel et al., 2010). The presence of bacteria in the uterus in the early postpartum period causes inflammation, histological lesions, and the delay of uterine involution (Sheldon et al., 2006). Intrauterine bacterial contamination is a physiological process that occurs during the early postpartum period (Kundsen et al., 2016). However, previous studies have shown that bacteria could be present for much longer period. Karstrup et al. (2017) reported opportunistic pathogenic bacteria in a pregnant cow uterus. There is little information about repeat breeding and intrauterine pathogens in dairy cows (Pothmann et al., 2015). McDougall (2005) concluded that further research is needed regarding bacteriological findings of repeat breeding cow uteri. Repeat breeding is also associated with ovarian dysfunction or impaired function (Kendall et al., 2009). Repeat breeding has also been interpreted as cyclic in cows (Heuwieser et al., 1997). However, ovarian activity around insemination is also not been clearly known (Pothmann et al., 2015).

In the present study, we hypothesize that uterine contamination by $T$. pyogenes in the early postpartum period may persist in later stages. Consequently, subclinical endometritis may lead to repeat breeder syndrome. This study aims to describe the presence of $T$. pyogenes in uterus, their status of antimicrobial resistance and association with cytological endometrial inflammation in repeat breeder cows. The results may be helpful in treatment or prevention of repeat breeding in dairy cows.

\section{MATERIALS AND METHODS}

\section{Animals}

The present study used the reproductive organs of 32 cows culled from various herds and slaughtered in one abattoir in Ankara, Turkey.

Age, breed, parity, calving assistance, and postpartum uterine disorders (i.e. metritis, endometritis, or pyometra), interval from calving to first artificial insemination (AI), and number of inseminations were recorded. The body condition score (BCS) before slaughtering (Ferguson et al., 1994). Metritis was marked by as inflammation of the uterus within the first 10 days postpartum with the presence of vaginal discharge and systemic signs of illness, while endometritis was marked by inflammation of the endometrium later in lactation with vaginal discharge, without any systemic signs. Pyometra was identified by accumulation of purulent material within the uterine lumen in the presence of a persistent corpus luteum and a closed cervix without systemic signs (Sheldon et al., 2006).
Cows with at least one corpus luteum were considered cyclic, whereas, those with no active or regressed corpus luteum and with incidental small follicles were considered anovulatory (Polat et al., 2015).

Samples were divided into two groups according to intrauterine bacteria. Cows showing the presence of $T$. pyogenes from the uterine samples were included in the infected group, while cows with no bacterial presence in the uterine samples were labelled as control group.

\section{Uterine cytology and bacteriologic culture}

Endometrial samples were collected with cytotape technique for cytological examination (Pascottini et al., 2015). Cytological slides were prepared by rolling the tape onto a clean glass microscope slide, drying, fixing and staining by laboratory procedure. The percentage of PMN was evaluated by counting 300 cells under a microscope at 400x magnification. A proportion of 3\% or greater PMN was defined as subclinical endometritis (Salasel et al., 2010). For the bacteriological sampling the uterine surface was washed with sterile saline solution and sterilized with iodine solution. The serosa of uteri was incised with a scalpel, and aseptic and sterile swabs passed through the incision.

\section{Bacterial isolation and identification}

A total of 32 uterus swabs obtained from the cows were investigated. After bacterial cultivation on brain heart infusion agar (Oxoid), the isolates were grown on agar supplemented with 5\% sheep blood and MacConkey agar (Oxoid) at $37^{\circ} \mathrm{C}$ for $48 \mathrm{~h}$ under aerobic and anaerobic conditions. This was followed by Gram staining and biochemical tests for catalase, oxidase, urease, nitrate reduction, fermentation of glucose, lactose, maltose, mannitol, sucrose, gelatin, and esculin hydrolysis.

For molecular identification of $T$. pyogenes isolates and sequence analysis of the 16S rDNA gene. DNA was extracted with genomic DNA isolation kit (QIAamp DNA Mini Kit; Qiagen). The universal primers 27-F AGAGTTTGATCMTGGCTCAG and 1492-R GGTTACCTTGTTACGACTT were used in the sequence analysis (Lane, 1991). A total volume of $25 \mu \mathrm{l} \mathrm{PCR} \mathrm{mix,}$ consisting of $3 \mathrm{mM} \mathrm{MgCl}$ (Thermo Fischer Scientific, USA), $0.2 \mathrm{mM}$ dNTPs (10 mM dNTP mix; Thermo Fischer Scientific, USA), $0.2 \mu \mathrm{M}$ of each primer, $2.5 \mu \mathrm{l}$ PCR reaction buffer, 2U Taq DNA polymerase (Thermo Fischer Scientific, USA), and $2 \mu$ template DNA was used. The PCR amplification conditions were as follows: $94^{\circ} \mathrm{C}$ for $4 \mathrm{~min}$., 35 cycles of $94^{\circ} \mathrm{C}$ for $30 \mathrm{sec}, 58^{\circ} \mathrm{C}$ for $30 \mathrm{sec}, 72^{\circ} \mathrm{C}$ for $1 \mathrm{~min}$, and a final extension step of $72^{\circ} \mathrm{C}$ for $6 \mathrm{~min}$. The amplified PCR products were visualized on $1.5 \%$ agarose gel (Promega Corporation, USA) with 
SafeView Classic (Applied Biological Materials, Canada) in gel electrophoresis apparatus.

After amplification, the PCR products were purified using ExoSAP-IT PCR Product Cleanup reagent (Thermo Scientific, USA). A BigDye Direct Cycle Sequencing Kit (Thermo Scientific, USA) was used for the sequence analysis according to the instructions. Sephadex G-50 (Sigma-Aldrich) was used to purify the amplicons and the sequence analysis was performed in an Applied Biosystems 3500 Genetic Analyzer (Applied Biosystems). CLC Main Workbench software version 7 was used for analyzing the sequences.

\section{Antimicrobial susceptibility tests}

Disc diffusion was used to detect antimicrobial resistance in the strains f based on the CLSI 2019 standard protocol. The following discs were used: ampicillin (AMP: $10 \mu \mathrm{g}$ ), bacitracin (B: $10 \mathrm{U})$, ceftiofur (EFT: 30 $\mu \mathrm{g}$ ), cefotaxime (CTX: $30 \mu \mathrm{g}$ ), chloramphenicol (C: $30 \mu \mathrm{g}$ ), erythromycin (E: $15 \mu \mathrm{g}$ ), gentamicin (GM: 10 $\mu \mathrm{g}$ ), lincomycin (MY: $15 \mu \mathrm{g}$ ), neomycin ( $\mathrm{N}: 30 \mu \mathrm{g}$ ), oxytetracycline (OT: $30 \mu \mathrm{g}$ ), ofloxacin (OFX: $5 \mu \mathrm{g}$ ), penicillin $\mathrm{G}(\mathrm{P}: 10 \mathrm{U})$, streptomycin $(\mathrm{S}: 10 \mu \mathrm{g})$, tetracycline (TE: $30 \mu \mathrm{g}$ ), ceftazidime (CAZ: $30 \mu \mathrm{g}$ ). Escherichia coli ATCC 25922 and Pseudomonas aeruginosa ATCC 27853 were used as positive controls in all tests.

\section{PCR amplification for tetracycline-resistance gene}

All tetracycline-resistant isolates were investigated for the presence of tet $W$ gene by PCR as described by Billington et al. (2006). The protocol was as follows: a $25 \mu \mathrm{l}$ PCR mixture containing $3 \mathrm{mM} \mathrm{MgCl}$ (Thermo Fischer Scientific, USA), $0.2 \mathrm{mM}$ dNTPs (10 mM dNTP mix; Thermo Fischer Scientific, USA), $0.2 \mu \mathrm{M}$ of each primer (tetW-F GACAACGAGAACGGACACTATG and tetW-R CGCAATAGCCAGCAATGAACGC), $2.5 \mu \mathrm{l}$ PCR reaction buffer, $2 \mathrm{U}$ Taq DNA polymerase (Thermo Fischer Scientific, USA), and $2 \mu$ template DNA. PCR amplifications were as follows: $95^{\circ} \mathrm{C}$ for $5 \mathrm{~min}, 35$ cycles of $95^{\circ} \mathrm{C}$ for $30 \mathrm{sec}, 55^{\circ} \mathrm{C}$ for $30 \mathrm{sec}, 72^{\circ} \mathrm{C}$ for $30 \mathrm{sec}$, and a final extension step of $10 \mathrm{~min}$ at $72^{\circ} \mathrm{C}$. PCR products were analyzed under a UV illuminator as described above.

\section{Statistical analysis}

Before performing the statistical analysis, the data were examined using the Shapiro-Wilk test for normality to meet parametric test assumptions. Student $t$ test and MannWhitney u test were used to evaluate the between-group differences for BCS, number of inseminations, pregnancy to first AI interval, and pregnancy to culling interval. Fisher exact test was used to compare the group frequencies for $\mathrm{SE}$, breed, and pp uterine infection. Logistic regression was used to determine which risk factors may influence the in uteri presence of $T$. pyogenes in repeat breeder cows. The model included subclinical endometritis $(0 \%, \geq 3 \%)$, parity, BCS, calving (i.e. no assistance), uterus infection (no, yes), calving to first artificial insemination interval, calving to culling interval, and number of inseminations, with odds ratios and $95 \%$ confidence intervals were calculated for all variables. $\mathrm{P}<0.05$ was considered as significant in all analyses. Data were analyzed with Stata 12/MP4 statistical software program.

\section{RESULTS}

Fifteen isolates identified as T. pyogenes from 32 repeat breeder animals were biochemically analyzed and nucleotide of mitocondrial (16) rDNA gene. Half of the animals were crossbred (Native Black x Brown Swiss) while the other half were Holsteins in the present study. $21.8 \%$ of the cows were primiparous while the others were multiparous. The mean BCS was within the ideal range; $46.8 \%$ of all cows had calving assistance while the other half had normal parturition; $43.7 \%$ of all cows had early postpartum uterine infection; $59.3 \%$ of the cows had the largest follicles (regressing) in the presence of a CL; 31.2\% had preovulatory follicles; $9.3 \%$ had anovulatory follicles. $60 \%$ of cows which isolated T. pyogenes had corpus luteum; on the other hand, $76.4 \%$ of cows had corpus luteum in non-presence of $T$. pyogenes. The proportion of subclinical endometritis was $37.5 \%$ for all animals in the present study. The mean calving to first insemination interval was 102.1 days with a range of 45 to 174 days and the average calving to culling interval was 291.4 days with a range of 160 to 450 days for cows that presence of $T$. pyogenes. Table I shows

Table I. Proportion of variables and occurance of $T$. pyogenes in repeat breeder cows.

\begin{tabular}{|c|c|c|c|c|c|c|c|}
\hline Group & SE & $\begin{array}{l}\text { Cross } \\
\text { breed }\end{array}$ & BCS & $\begin{array}{l}\text { PP uterine } \\
\text { infection }\end{array}$ & $\begin{array}{l}\text { Pregnancy to } \\
\text { first AI interval }\end{array}$ & $\begin{array}{l}\text { Pregnancy to } \\
\text { culling interval }\end{array}$ & $\begin{array}{l}\text { No. of insem- } \\
\text { inations }\end{array}$ \\
\hline Infection & $40 \%$ & $47.0 \%$ & $3.06(2.0-4.0)$ & $47 \%$ & $102.1(45-174)$ & $291.4(160-450)$ & $7.8(5-11)$ \\
\hline Control & $35.3 \%$ & $53.3 \%$ & $3.15(4.25-2.0)$ & $40 \%$ & $98.1(62-150)$ & $241.2(169-420)$ & $7.2(4-14)$ \\
\hline$P$ value & 0.647 & 0.993 & 0.662 & 0.735 & 0.708 & 0.08 & 0.551 \\
\hline
\end{tabular}

Abbreviations: SE, subclinic endometritis; BCS, body condition score; PP, postpartum; AI, artificial insemination. 
the distribution of parameters according to the presence of T. pyogenes. The logistic regression model revealed no effect of breed, parity, BCS, calving assistance, or postpartum uterine diseases on presence of $T$. pyogenes in repeat breeder cows (Table II).

Table II. Effect of variables included in a binary logistic regression model on presence of $T$. pyogenes in repeat breeder cows.

\begin{tabular}{llll}
\hline Variables & OR & $\mathbf{9 5 \%}$ CI & P value \\
\hline Breed & 0.41 & $0.06-2.56$ & 0.338 \\
Subclinical endometritis & 0.28 & $0.04-1.95$ & 0.197 \\
Parity & 1.22 & $0.52-2.87$ & 0.647 \\
BCS & 2.01 & $0.36-11.22$ & 0.426 \\
Calving & 3.14 & $0.34-28.77$ & 0.312 \\
Pp uterine infection & 2.27 & $0.27-19.20$ & 0.451 \\
Calving-first AI interval & 1.02 & $0.98-1.06$ & 0.282 \\
Calving-culling interval & 0.98 & $0.96-1.00$ & 0.104 \\
No. of inseminations & 1.19 & $0.70-2.03$ & 0.526 \\
\hline
\end{tabular}

Abbreviations: BCS, body condition score; PP, postpartum; AI, artificial insemination; OR, odds ratio; $\mathrm{CI}$, confidence interval. Variables: Breed (reference-Native Black, 1- Holstein), subclinical endometritis (reference- $0 \%, 1-\geq 3 \%$ ), parity (refence- primiparous, 1 - multiparous), BCS (reference- $>3.5,1-\leq 3.5$ ), Caving (reference- no assistance, 1assistance), and $\mathrm{Pp}$ uterine infection (reference- no, 1- yes).

Table III. Antimicrobial susceptibility of $15 \mathrm{~T}$. pyogenes isolates.

\begin{tabular}{llll}
\hline Antimicrobial agent & \multicolumn{3}{c}{ Number of isolates (\%) } \\
\cline { 2 - 4 } & Susceptible & Intermediate & Resistant \\
\hline Ampicillin (AMP) & $15(100)$ & $0(0)$ & $0(0)$ \\
Bacitracin (B) & $0(0)$ & $0(0)$ & $15(100)$ \\
Ceftiofur (EFT) & $15(100)$ & $0(0)$ & $0(0)$ \\
Cefotaxime (CTX) & $15(100)$ & $0(0)$ & $0(0)$ \\
Ceftazidime (CAZ) & $15(100)$ & $0(0)$ & $0(0)$ \\
Chloramphenicol (C) & $15(100)$ & $0(0)$ & $0(0)$ \\
Erythromycin (E) & $15(100)$ & $0(0)$ & $0(0)$ \\
Gentamicin (CN) & $15(100)$ & $0(0)$ & $0(0)$ \\
Lincomycin (MY) & $13(86.6)$ & $0(0)$ & $2(13.3)$ \\
Neomycin (N) & $0(0)$ & $0(0)$ & $15(100)$ \\
Ofloxacin (OFX) & $15(100)$ & $0(0)$ & $0(0)$ \\
Oxytetracycline (OT) & $0(0)$ & $0(0)$ & $15(100)$ \\
Penicilline (P) & $15(100)$ & $0(0)$ & $0(0)$ \\
Streptomycine (S) & $15(100)$ & $0(0)$ & $0(0)$ \\
Tetracycline (TE) & $0(0)$ & $0(0)$ & $15(100)$ \\
\hline
\end{tabular}

The S-typed, beta-hemolytic colonies on blood agar were observed after $48 \mathrm{~h}$ incubation under $5 \% \mathrm{CO}_{2}$. Under microscopic investigation, Gram-positive, small, pleomorphic bacteria were detected. Since all T. pyogenes strains had the same $16 \mathrm{~S}$ rDNA sequence, only one strain was selected and deposited in the NCBI under GenBank accession number MN907639.

\section{Antimicrobial susceptibility tests}

The susceptibility of $T$. pyogenes strains to 15 antibiotics is shown in Table III. The strains were most resistant to bacitracin, tetracycline, neomycin, and oxytetracycline, two isolates $(13.3 \%)$ were resistant only to lincomycin. The strains resistant to at least three or more antibiotics were defined as multiple drug-resistant (MDR). Fifteen multiple-drug resistance strains were detected $(100 \%)$. Fifteen strains were resistant to B, N, OT, TE while 2 strains were resistant to MY.

The tet $(W)$ gene was observed phenotypically in all tetracycline-resistant strains $(100 \%)$.

\section{DISCUSSION}

Previous studies have shown varying prevalence of subclinical endometritis in cows (LeBlanc, 2008; Plöntzke et al., 2010; Senosy et al., 2012). However, these studies focused on the early postpartum period. According to Pothman et al. (2015), there is little information about subclinical endometritis prevalence in repeat breeder cows. Salasel et al. (2010) and Pothman et al. (2015) reported subclinical endometritis prevalence of $52.7 \%$ and $12.7 \%$, respectively, which suggests that subclinical endometritis might be a risk factor for repeat breeder cows. The different reported percentages depend on the number of animals used and methodology. The main methodological difference is the PMN threshold definition for diagnosing subclinical endometritis. While Salasel et al. (2010) used 3\%, Pothman et al. (2015) used two different categories: between $0 \%$ and $5 \%$ and greater than $5 \%$. In the same study, $48.2 \%$ of cytological samples from repeat breeder cows met the threshold of $0-5 \%$ prevalence. In the present study, the incidence of subclinical endometritis was $37.5 \%$. Our sample size was smaller than in other studies whereas the percentage of subclinical endometritis cows was slightly greater. A possible explanation for this could be the PMN threshold value defined for cytological samples. Calving to first AI interval was also greater than in Salasel et al. (2010) and Pothman et al. (2015). More cows in the present study had histories of previous uterine infections than in Pothman et al. (2015). Early postpartum uterine infection may increase the incidence of subclinical endometritis during the later stages of lactation. 
There were no significant interactions in the risk factors analyzed for the presence of $T$. pyogenes in repeat breeder cows, which may be due to the number of isolates. In contrast to Pothman et al. (2015), we only sampled a few cows. This limitation was because we only evaluated 2 groups of cows with detected $T$. pyogenes in uterine samples and no bacterial growth in uterine samples. Previous studies showed that $T$. pyogenes is less likely to be detected because it is an anaerobic organism. Previous studies also compared cows detected with different bacteriological cultures. The bacteriological tests of the uterine samples with or without endometritis and in early or late postpartum periods showed that the frequently isolated bacteria are T. pyogenes, E. coli, Pseudomonas sp., Streptococcus sp., Staphylococcus sp., Pasteurella multocida, Clostridium sp., Fusobacterium sp., and Bacteroides sp., According to the postpartum time and interaction of bacteria, E. coli is the predominant etiological factor of uterine infection in the first 10 days after parturition (Földi et al., 2006). An over-presence of $E$. coli coupled with depressed immune system resulted in metritis in dairy cows in the early postpartum period. $E$. coli is also a promoter microorganism for the development of uterine infection caused by $T$. pyogenes 15 days after parturition. T. pyogenes cooperates with Fusobacterium necrophorum and Prevotella melaninogenicus. T. pyogenes produces cholesterol-dependent cytotoxin (forming pores into the cell membrane) and a growth factor, pyolisin, for F. necrophorum. Both these factors affect the endometrial epithelial cell and possibly phagocytic cells (Miller et al., 2007; Sheldon et al., 2010). F. necrophorum and $P$. melaninogenicus produce substances that impair the local immune factors. Thus, the main factor $T$. pyogenes persists in the uterus for a long time even in pregnant cows (Miller et al., 2007; Karstrup et al., 2017). This mechanism may help explain the isolation of $T$. pyogenes at later stages of lactation in this study.

Antimicrobial resistance may prevent the elimination of $T$. pyogenes. As a result, T. pyogenes can persist in the uterine environment and be isolated at later stages of lactation. Tetracycline resistant $T$. pyogenes strains have been reported in several studies. Trinh et al. (2002) reported 70.6\% tetracycline resistant Arcanobacterium pyogenes strains in pigs. Guérin-Faublée et al. (1993) showed that $67 \%$ of $T$. pyogenes strains were resistant to tetracycline, doxycycline, and minocycline. Similarly, $74.5 \% T$. pyogenes strains isolated from cows with mastitis were resistant to tetracycline (Zastempowska and Lassa, 2012). Santos et al. (2010) and Liu et al. (2009) also reported tetracycline-resistant $T$. pyogenes strains isolated from the uterus of postpartum dairy cows with endometritis. Zhang et al. (2017) reported $62.5 \%$ and $68.7 \%$ resistance rates against oxytetracycline and tetracycline, respectively, among $32 T$. pyogenes strains isolated from dairy cows with endometritis. In our study, 15 T. pyogenes (100\%) strains were resistant to both oxytetracycline and tetracycline, which is a higher frequency than in previous studies.

Tet(W) is a globally distributed tetracycline resistance gene. Studies have shown that it is associated with tetracycline resistance in T. pyogenes. Zhang et al. (2017) found tet(W) genes in $53.1 \%$ of tetracycline-resistant $T$. pyogenes strains while Zastempowska and Lassa (2012) found tet(W) gene in $85.5 \%$ of tetracycline-resistant $T$. pyogenes. Billington et al. (2006) demonstrated that all tetracycline-resistant $T$. pyogenes isolates carry the tet $(\mathrm{W})$ gene. Similar results were obtained in this study: all tetracycline-resistant strains had this gene.

\section{CONCLUSION}

In conclusion, the presence of intrauterine $T$. pyogenes was not associated with cytological endometrial inflammation status in repeat breeder cows in this study. On the other hand, the presence of $T$. pyogenes can be detected in the later stages of lactation. This information may be useful in developing a treatment strategy for repeat breeder cows. However, further research is needed to determine the molecular role of the presence of intrauterine bacteria and subclinical endometritis in repeat breeder cows.

\section{ACKNOWLEDGMENTS}

The authors would like to thank Mr. John H. Stanley for his excellent language editing, proofreading, and scientific critique of the article.

\section{Statement of conflict of interest}

The authors have declared no conflict of interest.

\section{REFERENCES}

Båge, R., Gustafsson, H., Larsson, B., Forsberg, M. and Rodriguez-Martinez, H., 2002. Repeat breeding in dairy heifers: Follicular dynamics and estrous cycle characteristics in relation to sexual hormone patterns. Theriogenology, 57: 2257-2269. https:// doi.org/10.1016/S0093-691X(02)00840-3

Billington, S.J. and Jost, B.H., 2006. Multiple genetic elements carry the tetracycline resistance gene tet $(W)$ in the animal pathogen Arcanobacterium pyogenes. Antimicrob. Agents Chemother, 50: 3580-3587. https://doi.org/10.1128/AAC.00562-06

Bondurant, R.H., 1999. Inflammation in the bovine female reproductive tract. J. Anim. Sci., 77: 101110. https://doi.org/10.2527/1999.77suppl_2101x 
Ferguson, J.D., Galligan, D.T. and Thomsen, N., 1994. Principal descriptors of body condition score in Holstein cows. J. Dairy Sci., 77: 2695-2703. https:// doi.org/10.3168/jds.S0022-0302(94)77212-X

Földi, J., Kulcsar, M., Pecsi, A., Huyghe, B., De Sa, C., Lohuis, J.A.C.M. and Huszenicza, G.Y., 2006. Bacterial complications of postpartum uterine involution in cattle. Anim. Reprod. Sci., 96: 265-281. https://doi.org/10.1016/j.anireprosci.2006.08.006

Gilbert, R.O., Shin, S.T., Guard, C.L., Erb, H.N. and Frajblat, M., 2005. Prevalence of endometritis and its effects on reproductive performance of dairy cows. Theriogenology, 64: 1879-1888. https://doi. org/10.1016/j.theriogenology.2005.04.022

Guérin-Faublée, V., Flandrois, J.P., Broye, E., Tupin, F. and Richard, Y., 1993. Actinomyces pyogenes: susceptibility of 103 clinical animal isolates to 22 antimicrobial agents. Vet. Res., 24: 251-259.

Gustafsson, H. and Emanuelson, U., 2002. Characterisation of the repeat breeding syndrome in swedish dairy cattle. Acta Vet. Scand., 43: 115125. https://doi.org/10.1186/1751-0147-43-115

Heuwieser, W., Oltenacu, P.A., Lednor, A.J. and Foote, R.H., 1997. Evaluation of different protocols for prostaglandin synchronization to improve reproductive performance in dairy herds with low estrus detection efficiency. J. Dairy Sci., 80: 2766-2774. https://doi.org/10.3168/jds.S00220302(97)76239-8

Huszenicza, G., Fodor, M., Gacs, M., Kulcsar, M., Dohmen, M. and Vamos, M., 1999. Uterine bacteriology, resumption of cyclic ovarian activity and fertility in postpartum cows kept in large-scale dairy herds. Reprod. Domest. Anim. 34: 237245. https://doi.org/10.1111/j.1439-0531.1999. tb01246.x

Karstrup, C.C., Klitgaard, K., Jensen, T.K., Agerholm, J.S. and Pedersen, H.G., 2017. Presence of bacteria in the endometrium and placentomes of pregnant cows. Theriogenology, 99: 41-47. https://doi. org/10.1016/j.theriogenology.2017.05.013

Kendall, N.R., Flint, A.P.F. and Mann, G.E., 2009. Incidence and treatment of inadequate postovulatory progesterone concentrations in repeat breeder cows. Vet. J., 181: 158-162. https://doi.org/10.1016/j. tvj1.2008.02.015

Knudsen, L.R.V., Karstrup, C.C., Pedersen, H.G., Angen, Ø., Agerholm, J.S., Rasmussen, E.L. and Klitgaard, K., 2016. An investigation of the microbiota in uterine flush samples and endometrial biopsies from dairy cows during the first 7 weeks postpartum. Theriogenology, 86: 642-650. https:// doi.org/10.1016/j.theriogenology.2016.02.016

Lane, D.J., 1991. 16S/23S rRNA Sequencing. In: Nucleic acid techniques in bacterial systematic (eds. E. Stackebrandt and M. Goodfellow). John Wiley and Sons, New York, USA. pp. 115-175.

LeBlanc, S.J., 2008. Postpartum uterine disease and dairy herd reproductive performance: A review. Vet. J., 176: 102-114. https://doi.org/10.1016/j. tvj1.2007.12.019

Liu, M.C., Wu, C.M., Liu, Y.C., Zhao, J.C., Yang, Y.L. and Shen, J.Z., 2009. Identification, susceptibility, and detection of integron-gene cassettes of Arcanobacterium pyogenes in bovine endometritis. J. Dairy Sci., 92: 3659-3666. https:// doi.org/10.3168/jds.2008-1756

Lopez-Gatius, F., Yaniz, J.L., Santolaria, P., Murugavel, K., Guijarro, R., Calvo, E. and Lopez-Bejar, M., 2004. Reproductive performance of lactating dairy cows treated with cloprostenol at the time of insemination. Theriogenology, 62: 677-689. https:// doi.org/10.1016/j.theriogenology.2003.11.014

McDougall, S., 2005. Gross abnormalities, bacteriology and histological lesions of uteri of dairy cows failing to conceive or maintain pregnancy. N.Z. Vet. J., 53: 253-256. https://doi. org/10.1080/00480169.2005.36555

Miller, A.N.A., Williams, E.J., Sibley, K., Herath, S., Lane, E.A., Fishwick, J., and Sheldon, I.M., 2007. The effects of Arcanobacterium pyogenes on endometrial function in vitro, and on uterine and ovarian function in vivo. Theriogenology, 68: $\quad 972-980 . \quad \mathrm{https}: / /$ doi.org/10.1016/j. theriogenology.2007.07.013

Pascottini, O.B., Dini, P., Hostens, M., Ducatelle, R. and Opsomer, G., 2015. A novel cytologic sampling technique to diagnose subclinical endometritis and comparison of staining methods for endometrial cytology samples in dairy cows. Theriogenology, 84: $\quad 1438-1446$. https://doi.org/10.1016/j. theriogenology.2015.07.032

Pérez-Marín, C.C. and España, F., 2007. Oestrus expression and ovarian function in repeat breeder cows, monitored by ultrasonography and progesterone assay. Reprod. Domest. Anim., 42: 449-456. https://doi.org/10.1111/j.14390531.2006.00805.x

Plöntzke, J., Madoz, L.V., De la Sota, R.L., Drillich, M. and Heuwieser, W., 2010. Subclinical endometritis and its impact on reproductive performance in grazing dairy cattle in Argentina. Anim. Reprod. Sci., 122: 52-57. https://doi.org/10.1016/j. anireprosci.2010.07.006 
Polat, I.M., Alçiğir, E., Pekcan, M., Vural, S.A., Özenç, E., Canatan, H.E., Küplülü, Ş., Dal, G.E., Yazlık, M.O., Baklac1, C. and Vural, M.R., 2015. Characterization of transforming growth factor beta superfamily, growth factors, transcriptional factors, and lipopolysaccharide in bovine cystic ovarian follicles. Theriogenology, 84: 1043-1052. https:// doi.org/10.1016/j.theriogenology.2015.06.003

Pothmann, H., Prunner, I., Wagener, K., Jaureguiberry, M., de la Sota, R.L., Erber, R. and Drillich, M., 2015. The prevalence of subclinical endometritis and intrauterine infections in repeat breeder cows. Theriogenology, 83: 1249-1253. https://doi. org/10.1016/j.theriogenology.2015.01.013

Salasel, B., Mokhtari, A. and Taktaz, T., 2010. Prevalence, risk factors for and impact of subclinical endometritis in repeat breeder dairy cows. Theriogenology, 74: 1271-1278. https://doi. org/10.1016/j.theriogenology.2010.05.033

Santos, T.M.A., Caixeta, L.S., Machado, V.S., Rauf, A.K., Gilbert, R.O. and Bicalho, R.C., 2010. Antimicrobial resistance and presence of virulence factor genes in Arcanobacterium pyogenes isolated from the uterus of postpartum dairy cows. Vet. Microbiol., 145: 84-89. https://doi.org/10.1016/j. vetmic.2010.03.001

Senosy, W.S., Izaike, Y., and Osawa, T., 2012. Influences of metabolic traits on subclinical endometritis at different intervals postpartum in high milking cows. Reprod. Domest. Anim., 47: 666-674. https:// doi.org/10.1111/j.1439-0531.2011.01941.x

Sheldon, I.M, Lewis, G.S., LeBlanc, S. and Gilbert, R.O., 2006. Defining postpartum uterine disease in cattle. Theriogenology, 65: 1516-1530. https://doi. org/10.1016/j.theriogenology.2005.08.021

Sheldon, I.M., Cronin, J., Goetze, L., Donofrio, G. and Schuberth, H.J., 2009. Defining postpartum uterine disease and the mechanisms of infection and immunity in the female reproductive tract in cattle. Biol. Reprod., 81: 1025-1032. https://doi. org/10.1095/biolreprod.109.077370

Sheldon, I.M., Rycroft, A.N., Dogan, B., Craven, M., Bromfield, J.J., Chandler, A. and Simpson, K.W., 2010. Specific strains of Escherichia coli are pathogenic for the endometrium of cattle and cause pelvic inflammatory disease in cattle and mice. PLoS One, 5: e9192. https://doi.org/10.1371/ journal.pone.0009192

Trinh, H.T., Billington, S.J., Field, A.C., Songer, J.G. and Jost, B.H., 2002. Susceptibility of Arcanobacterium pyogenes from different sources to tetracycline, macrolide and lincosamide antimicrobial agents. Vet. Microbiol., 85: 353-359. https://doi.org/10.1016/S0378-1135(01)00524-7

Williams, E.J., Fischer,D.P., Noakes,D.E., England, G.C., Rycroft, A., Dobson, H. and Sheldon, I.M., 2007. The relationship between uterine pathogen growth density and ovarian function in the postpartum dairy cow. Theriogenology, 68: 549-559. https:// doi.org/10.1016/j.theriogenology.2007.04.056

Yazlik, M.O., Çolakoğlu, H.E., Polat, İ.M., Aloğlu, E., Baklaci, C., Kaya, U., Vural, M.R., Aktuğ, E., Kurt, S., Öz, B., Yağc1, G. and Küplülü Ş., 2018. Rumination time and physical activity monitoring, milk yield changes around estrus and first service pregnancy rate in dairy cows assigned to voluntary waiting period. Isr. J. Vet. Med., 73: 8-13.

Yusuf, M., Nakao, T., Ranasinghe, R.B.K., Gautam, G., Long, S.T., Yoshida, C. and Hayashi, A., 2010. Reproductive performance of repeat breeders in dairy herds. Theriogenology, 73: 1220-1229. https:// doi.org/10.1016/j.theriogenology.2010.01.016

Zastempowska, E. and Lassa, H., 2012. Genotypic characterization and evaluation of an antibiotic resistance of Trueperella pyogenes (Arcanobacterium pyogenes) isolated from milk of dairy cows with clinical mastitis. Vet. Microbiol., 161: 153-158. https://doi.org/10.1016/j. vetmic.2012.07.018

Zerbe, H., Ossadnik, C., Leibold, W. and Shuberth, H.J. 2001. Influence of Escherichia coli and Arcanobacterium pyogenes isolated from bovine puerperal uteri on phenotypic and functional properties of neutrophils. Vet. Microbiol., 79: $351-365$. https://doi.org/10.1016/S03781135(00)00368-0

Zhang, D., Zhao, J., Wang, Q., Liu, Y., Tian, C., Zhao, Y. and Liu, M., 2017. Trueperella pyogenes isolated from dairy cows with endometritis in Inner Mongolia, China: Tetracycline susceptibility and tetracycline-resistance gene distribution. Microb. Pathog., 105: 51-56. https://doi.org/10.1016/j. micpath.2017.02.010

Zhang, W., Liu, X., Liu, M., Ma, B., Xu, L. and Wang, J., 2017. Development of a multiplex PCR for simultaneous detection of Pasteurella multocida, Mannheimia haemolytica and Trueperella pyogenes. Acta Vet. Hung., 65: 327-339. https://doi. org/10.1556/004.2017.032 